\title{
“AyurVirDB" Ayurvedic database for virus cure
}

\author{
Research Article
}

\section{Richa Gupta1, Akshara Pande², Amit Gupta ${ }^{3}$, Rishika Yadav³, Navin Garg ${ }^{4}$, Aditi Sharma5, Kumud Pant', Preeti Chaudhary ${ }^{3}$, Lisa Gopal ${ }^{3}$}

\author{
1. Assistant Professor, Computer Science Engineering, 2. Associate Professor, School of Computing, 3. Assistant \\ Professor, Computer Science Engineering, 4. HOD \& Associate Professor, Computer Science Engineering, \\ Graphic Era Hill University Dehradun. \\ 5. Student, Department of Life Sciences, 6. Associate Professor, Department of Biotechnology, \\ Graphic Era Deemed to be University, Dehradun.
}

\begin{abstract}
Background \& Objective: Ayurveda, the "Mother of all healing", has existed for over 5,000 years and hence is considered to be the oldest healing science. Ayurveda states that the mind can heal and transform a person's whole being as the mind and body are associated. Herbs are the heart of Ayurvedic belief. They are used to boost defense against diseases and viruses and keep the brain, body, and soul in complete balance. Although ayurvedic medicines and herbs have natural components, they should still be used with certain precautions under the supervision of a medical practitioner. This study aims to manually curate information for the various ayurvedic medicinal herbs that have antiviral activity against harmful viruses. Methods: Detailed information is collected from the literature regarding the following (a) types of viruses (b) which particular category they belong to(c) the respective components of herbs that are responsible for curing viruses. We developed a web interface with the help of php and mysql to get the desired output. Results: The database consists of 104 viruses and 704 natural components. The web server is available at: http://ayurvir.com. Interpretation \& Conclusion: We believe that AyurVirDB database will be extremely beneficial for the research community. It not only aids in investigations of Ayurvedic medicinal plants and their components. On the emergence or re-emergence of a virus, one could be able to predict the ayurvedic plants/herbs used for viral treatment based on virus similarity or disease symptoms.
\end{abstract}

Key Words: Ayurvedic herbs, Ayurvedic plants, Antiviral activity, Database, Natural product, Viruses.

\section{Introduction}

The evolution of Ayurveda has been done by seers (rishis) long before centuries of examination, assays, discussions, and meditations. The origin of Ayurvedic medications has been recorded in the 'Atharva Veda'. The teachings of Ayurveda were regularly passed on to students by their teachers, the first summary of these teachings was put into writings around 1500 B.C. (1)

Ayurveda is the blend of two Sanskrit words, "Ayur" and "Veda". The term "Ayur" refers to life and the term "Veda" states to science. It is believed that any physical disorder is caused by the unbalanced and stressful lifestyles of humans. Ayurveda empowers certain ways of common treatments to recover a harmony between the body, brain, soul, and the earth. The essential premises of ayurvedic medication are

\section{* Corresponding Author:}

Akshara Pande

Associate Professor,

School of Computing,

Graphic Era Hill University (GEHU),

Dehradun. India

Email Id: pandeakshara@gmail.com prakriti, doshas, and the interconnectedness of the human body (2).

Ayurvedic treatment helps by removing impurities, diminishing side effects, and expanding protection from the ailment, and lessening stress. Herbs and different plants are used widely in Ayurvedic treatment (3). Since ancient times, plants have been used for their various medicinal properties. As is natural and harmless and herbal medicines being the popular form of therapy. Traditional, herbal, and ayurvedic medicine is becoming increasingly popular all over the world, with many immedicable conditions responding to it well. Such types of medication as conventional Chinese medication, Ayurveda, Kampo, customary Korean medication, and Unani have been polished in mainly certain area of the world \& have bloomed into precisely directed frameworks of medication (4). The WHO determines different traditional medication as the sum of apprehension, expertise, and practices based on speculation and experience indigenous to distinct cultures (5).

The term "Janapadodhwamsa" in Ayurveda is believed to be related to epidemics, where it is referenced that because either of disturbed Vayu (air), Jala (water), Desha (territory), and Kala (seasons), certain maladies emerge which destroy population (6). One of such maladies arises due to the spread of 
viruses, though scourges of viral diseases happen at a big interval of years. Recently we have seen the outbreak of the SARS-Cov2 virus. Existing circumstance requests that more exploration is expected to correctly recognize the methods of transmission and clinical countermeasures, particularly the preventive viewpoint.

The viruses broadly can be classified into three categories: DNA virus, RNA virus, and Retrovirus, which are further divided into 9 categories of viruses (Figure 1). As shown in Figure 1, these 9 viruses belong to 7 families (7).

Figure 1. Virus classification. The family of the virus is written inside the bracket

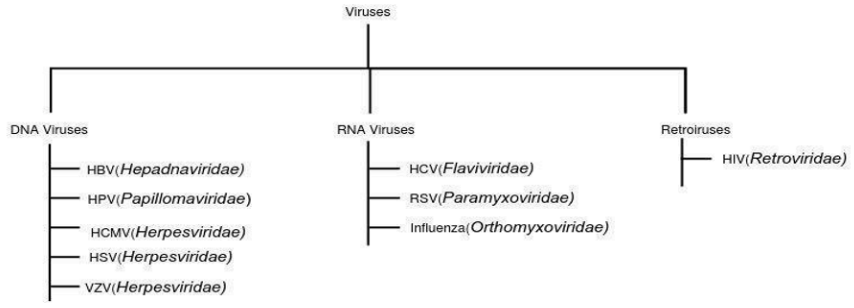

\section{Mechanism of action: How do Viruses infect the host cell?}

Viruses occur in a large variety of shapes but follow the same basic pattern with an envelope and proteins which has a key role in viral attachment to the host cell. After successful attachment, the virus replicates its DNA inside the host and forces it to produce more viruses by hijacking the host's proteinmaking machinery. Finally assembled viruses leave the cell in turn infecting other cells (8). The mechanism of action of various viruses is depicted in Figure 2.

\section{Figure2. Schematic representation of Virus Mechanism of Action to infect a host cell}

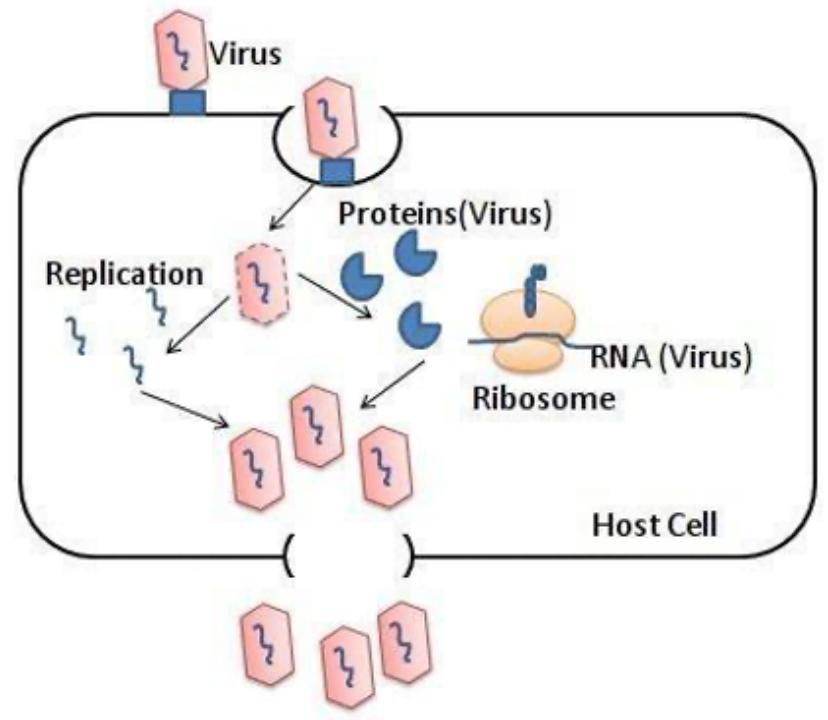

Here we are considering the mechanism of action of some of the recently emerged viruses such as Ebola, Zika, and Coronavirus that require attention. Ebola virus takes advantage of macropinocytosis to ensure its entry inside a human cell. Proteins present on the surface of the pathogen act as receptors that allow immune cells torecognize the dead cell debris, the virus displays interaction with the proteins, called T-cell immunoglobulin and mucin domain (TIM) proteins, and utilize them to take over its way into the cell. When the Ebola virus moves inside, there happens a fusion between its membrane and the endosome which is formed around releasing its intrinsic substance (genetic) into the cell. Viral RNA then assumes control over the mechanism of cells to form proteins and replicate themselves inside, further budding off the membrane forming a new virus while the healthy host cell passes on (9).

The entry of Zika virus (ZIKV) is facilitated by the phosphatidylserine receptors like TIM (TIM1, TIM4) and TAM (Axl, Tyro3) in human primary trophoblasts, as the mosquito bite stays a significant course of transmission, subsequently, the main known targets for ZIKV infection are the cells localized in the epidermis and dermis (10). When ZIKV enters inside the host cell by endocytosis, the viral genome is released and virionsgatherforsubsequentinfection (11). Extensive determination within body tissues and fluids is caused due to the infection caused by ZIKV. This can be considered astrademark whichidentifies ZIKV from other arthropod-transmitted flaviviruses (11).

The spike proteins present on the surface of the coronavirus attach to the surface of host cells called Angiotensin Converting Enzyme2 (ACE2), which normally helps in regulating blood pressure. But upon binding of coronavirus, chemical changes start thus effectively fusing the membranes around the cell and virus together, hence permitting the entry of viral RNA inside the body cell. The virus then dominates the Protein making machinery of the host cell thus translating its RNA into new viral copies, a single cell can be authorized to create a huge number of new virions within hours subsequently infecting other healthy cells (12).

\section{Prevention: How Ayurveda protects the human body from virus attack?}

It is often seen around us thatsome people are prone to diseases repeatedly, while others do not have much effect. The reason behind this is our immune system. Nature has created an immune system in every living being, which protects it from invading pathogens. When due to any internal or external factors the immunity of the body becomes weak, the first effect is mostly seen in the form of cold, flu, cough, fever, etc. In Ayurveda few treatments are accessible for improving resistance. There are certain terms in Ayurveda such as AdidaivikaBalaPravrittaVyadhiinvolving diseases that arose because of certain causes which are not under the control of human intelligence, also, the terms, Sansargajaand Upsragajaindicate the contagious diseases along with airborne diseases. These infectious diseases can be managed either by prevention or cure according to Ayurveda (6).

When there is very little scientific knowledge about newly emerging viral diseases a carefulinsight can help in preparing plans and managing future 
outbreaks also. Prior detection helps in the rapid execution of effective measures thereby reducing the risk of disastrous spread (13). It is mentioned in Ayurveda that collective potent medicines should be used along with Shodhana(bio-purification) and Rasayana(immunomodulatory changes) only when required, especially in risk areas improving the immunity and thus reducing the risk of infection (6). According to Ayurveda, the development and multiplication of bacteria and viruses occur in the body only during the time of weak immunity, hence, the immune system needs to be boosted to fight against bacteria and viruses thus preventing diseases (14-16).
There are certain other plants like Ashwagandha [Withania somnifera], Guduchi [Tinospora cordifolia], Haridra [Curcuma longa], Musta [Cyperus rotundus], Pippali [Piper longum], Sunthi [Zingiber officinale], Tulsi [Ocimum sanctum], Yashtimadhu [Glycyrrhiza glabra] which are known to possess properties of immune-modulator, improving the overall defense mechanism of the body, thereby enhancing its ability to fight viral diseases and also playing an important role in preventing viral and bacterial outbreak (17). Some of the commonly used plant-derived immunomodulators listed against particular viruses are given in Table I.

Table I. Ordinary Plant-Derived Immunomodulators

\begin{tabular}{|c|c|c|c|c|c|}
\hline S.No & Common name & Scientific name and family & Part used & $\begin{array}{c}\text { Immune } \\
\text { against }\end{array}$ & Reference \\
\hline 1 & & $\begin{array}{l}\text { Aphanothecehalophytica Frémy } \\
\text { (Chroococcales) }\end{array}$ & Cyanobacterium & $\begin{array}{c}\text { Inhibits } \\
\text { influenza virus }\end{array}$ & (18) \\
\hline 2 & Marlberry & $\begin{array}{l}\text { Ardisia squamulosa C. Presl } \\
\text { (Myrsinaceae) }\end{array}$ & $\begin{array}{c}\text { Shrub, } \\
\text { Branches and } \\
\text { leaves }\end{array}$ & $\begin{array}{l}\text { Anti-HIV } \\
\text { property }\end{array}$ & (18) \\
\hline 3 & Garden Marigold & $\begin{array}{l}\text { Calendula Officinalis Linn. } \\
\text { (Asteraceae) }\end{array}$ & Flowers & $\begin{array}{l}\text { Anti-HIV } \\
\text { property }\end{array}$ & (18) \\
\hline 4 & Common plantain & $\begin{array}{l}\text { Plantago major Linn. } \\
\text { (Plantaginaceae) }\end{array}$ & Extract & $\begin{array}{l}\text { HSV-1, HSV-2, } \\
\text { adenoviruses }\end{array}$ & (19) \\
\hline 5 & Cat's Claw & $\begin{array}{l}\text { Uncaria tomentosa (Wild. ex Schultz.) DC. } \\
\text { (Rubiaceae) }\end{array}$ & Extract & $\begin{array}{l}\text { Dengue } \\
\text { Virus-2 }\end{array}$ & (20) \\
\hline 6 & Giloy & $\begin{array}{l}\text { Tinospora cordifolia Thunb. } \\
\text { (Menispermaceae) }\end{array}$ & Extract & HIV & (21) \\
\hline 7 & Garlic & $\begin{array}{l}\text { Allium sativum } \mathrm{L} . \\
\text { (Liliaceae ) }\end{array}$ & & Hepatitis & (22) \\
\hline 8 & Butterfly Bush & $\begin{array}{l}\text { Buddleja officinalis Maxim. } \\
\text { (Buddlejaceea) }\end{array}$ & & Hepatitis & (22) \\
\hline 9 & Tea plant & $\begin{array}{l}\text { Camellia sinensis (L.) Kuntze } \\
\text { (Theaceae) }\end{array}$ & & Hepatitis & $(22)$ \\
\hline 10 & Laurel-leaf cistus & $\begin{array}{l}\text { Cistus laurifoliusLinn. } \\
\text { (Cistaceae) }\end{array}$ & & Hepatitis & (22) \\
\hline 11 & & $\begin{array}{l}\text { Corydalis saxicola } \\
\text { (Papaveraceae) }\end{array}$ & & Hepatitis & (22) \\
\hline 12 & Daisy & $\begin{array}{l}\text { Eglets viscosaLess. } \\
\text { (Asteraceae ) }\end{array}$ & & Hepatitis & (22) \\
\hline 13 & Gardenia & $\begin{array}{l}\text { Gardenia jasminoides J. Ellis } \\
\text { (Rubiaceae) }\end{array}$ & & Hepatitis & (22) \\
\hline 14 & Ginkgo & $\begin{array}{l}\text { Ginkgo Biloba Linn. } \\
\text { (Ginkogoaceae) }\end{array}$ & & Hepatitis & (22) \\
\hline 15 & Levant cotton & $\begin{array}{l}\text { Gossypium herbaceum Linn. } \\
\text { (Malvaceae) }\end{array}$ & & Hepatitis & (22) \\
\hline 16 & Roselle, Hibiscus & $\begin{array}{l}\text { Hibiscus sabdariffa Linn. } \\
\text { (Malvaceae) }\end{array}$ & & Hepatitis & (22) \\
\hline 17 & $\begin{array}{l}\text { Creosote bushand } \\
\text { greasewood }\end{array}$ & $\begin{array}{l}\text { Larrea tridentata (DC.) Coville } \\
\text { (Zygophyllaceae) }\end{array}$ & & Hepatitis & (22) \\
\hline 18 & Magnolia & $\begin{array}{l}\text { Magnolia officinalis Rehder\& Wilson } \\
\text { (Magnoliaceae) }\end{array}$ & & Hepatitis & (22) \\
\hline 19 & Mango & $\begin{array}{l}\text { Mangifera indica Linn. } \\
\text { (Anacardiaceae) }\end{array}$ & & Hepatitis & (22) \\
\hline 20 & Black seed & $\begin{array}{l}\text { Nigella sativa Linn. } \\
\text { (Ranunculaceae) }\end{array}$ & & Hepatitis & (22) \\
\hline 21 & Basil & $\begin{array}{l}\text { Ocimumbasilicum Linn. } \\
\text { (Lamiaceae) }\end{array}$ & & Hepatitis & (22) \\
\hline 22 & Boldo & $\begin{array}{l}\text { Peumusboldus Molina. } \\
\text { (Monimiaceae) }\end{array}$ & & Hepatitis & (22) \\
\hline 23 & $\begin{array}{l}\text { Stonebreaker or } \\
\text { seed under leaf }\end{array}$ & $\begin{array}{l}\text { Phyllanthus amarus Linn. } \\
\text { (Phyllanthaceae) }\end{array}$ & & Hepatitis & (22) \\
\hline
\end{tabular}




\begin{tabular}{|c|c|c|c|c|}
\hline 24 & Pine & $\begin{array}{l}\text { Pinus maritima Aiton. } \\
\text { (Pinaceae) }\end{array}$ & Hepatitis & $(22)$ \\
\hline 25 & Indian madder & $\begin{array}{l}\text { Rubia cordifolia Linn. } \\
\text { (Rubiaceae) }\end{array}$ & Hepatitis & $(22)$ \\
\hline 26 & Magnolia-vine & $\begin{array}{l}\text { Schisandra chinensis (Turcz.) Baill. } \\
\text { (Schisandraceae) }\end{array}$ & Hepatitis & $(22)$ \\
\hline 27 & $\begin{array}{l}\text { Flannel weed, } \\
\text { bala }\end{array}$ & $\begin{array}{l}\text { Sida cordifolia Linn. } \\
\text { (Malvaceae) }\end{array}$ & Hepatitis & $(22)$ \\
\hline 28 & $\begin{array}{l}\text { Cardus marianus, } \\
\text { milk thistle, }\end{array}$ & $\begin{array}{l}\text { Silybum marianum (L.) Gaertn. } \\
\text { (Asteraceae) }\end{array}$ & Hepatitis & $(22)$ \\
\hline
\end{tabular}

Cure: Ayurveda helps to control and cure viral infections?

In the past various medicinal plants have been investigated and discovered against deadly virus infections (23-25). Medicinal herbs have the potential to inhibit both DNA and RNA viruses (26). The framework of ayurvedic medicines is one of the oldest frameworks and it incorporates different ethnopharmacological activities. The study of medicines obtained from natural products such as plants and fungi that are used for health-related issues is called Ethnopharmacology. The ethnopharmacological properties develop immunity to one's body, which in turn can prevent virus attacks by identifying them. There are two kinds of mechanisms possible for the immune system. One is humoral and the other is cellular immunity. Immunomodulators may help to stimulate, repressor regulates any facet of the immune system that involves both of its arms i.e. adaptive and innate immunity. Some plants may act as immunomodulators and in Indian traditional systems, they are known as Rasayanas(18).Rasayanais a Sanskrit word, which is made up of two words "Ras" and "Ayana". "Ras" means essence and "Ayana" means path. The mechanism of action of Rasayanas/ immunomodulators helps to recover from viral infections. The mechanism of action of Ayurvedic herbs/plants is shown in Figure 3.

In the present study, data on various ayurvedic formulations for the control of different viruses have been compiled from various studies. The details of a particular virus can be found in our database.

Figure 3: Work of action of Ayurvedic herbs

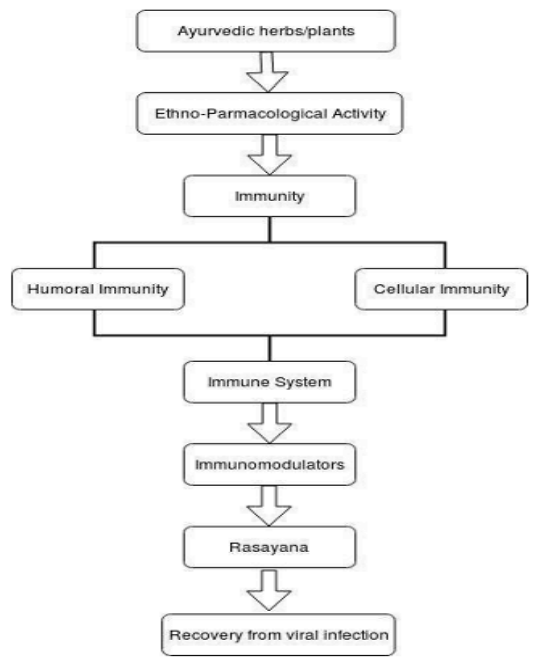

\section{Material and Method}

Data Source

We manually searched on Google about the engine for Ayurvedic plants which are helpful to cure different viruses. The information of data collected from Pubmed articles and non-PubMed articles is shown in Figure 4. The same information has been compiled in the database.

Figure 4. Data source information

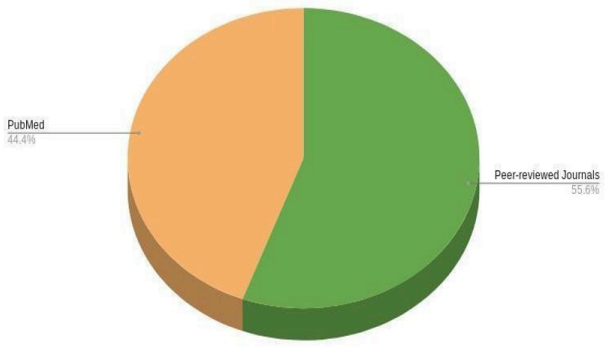

\section{Data Structure}

AyurVirDB consists of information on 409 DNA and 593 RNA viruses. A schematic diagram of AyurVirDB design is shown in Figure 5. Some of the prominent viruses and the plants that show antiviral properties against mentioned viruses are included in the database.

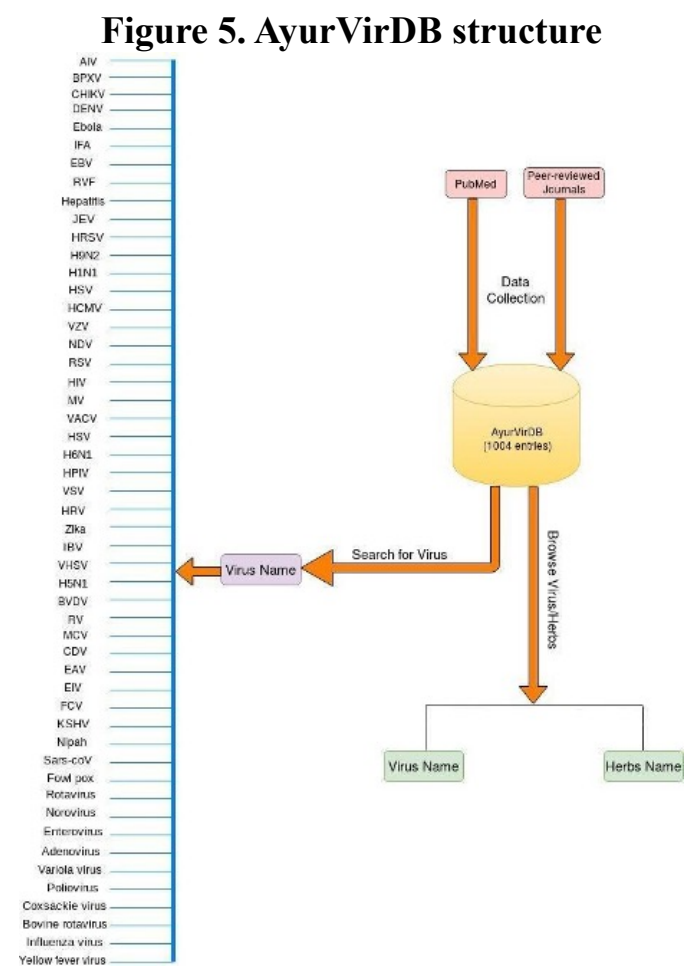




\section{Results}

\section{Database Statistics}

The distribution of viruses in various categories in the AyurVirDB database is illustrated in Figure 6. The information on retrovirus is scanty so is considered in the broad category of RNA viruses.

Figure 6. Distribution of Virus categories in AyurVirDB database

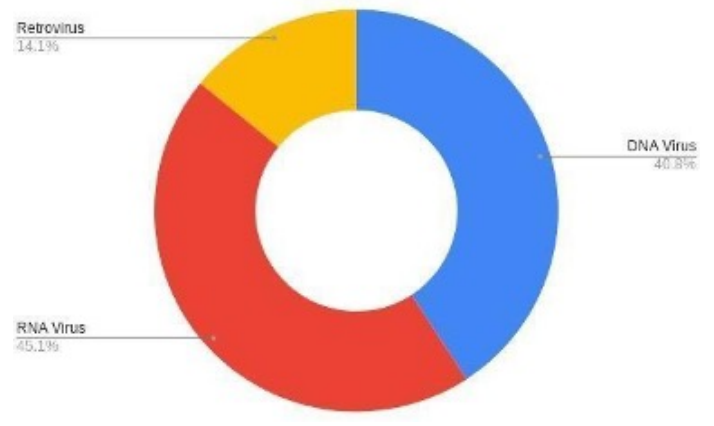

\section{Ayurvedic Plants against DNA Viruses}

DNA virus, as the name suggests, its genome is composed of Deoxyribonucleic acid (DNA) and can be replicated by the activity of DNA polymerase. DNA virus can be of two types: single-stranded DNA virus and double-stranded DNA virus. Herpesviruses are DNA viruses well known for their ability to cause various diseases. The distribution of DNA virus in the AyurVirDB database is shown in Figure 7. It is evident from the figure that maximum entries have been found for herpes simplex viruses (HSV).

\section{Figure 7. DNA virus distribution in AyurVirDB database}

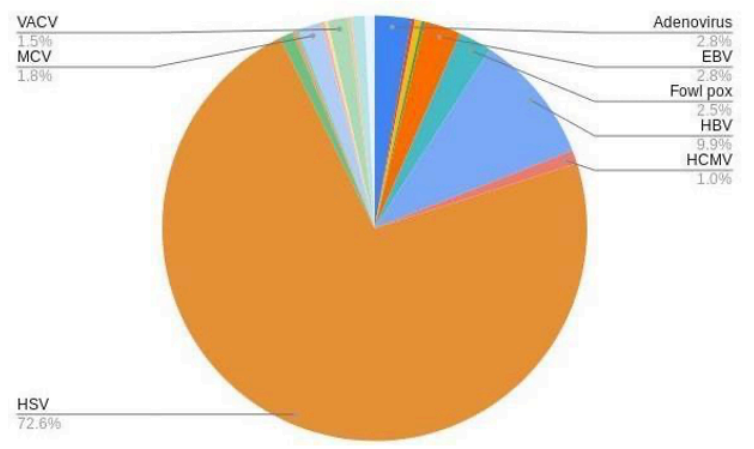

Herpesviridae is a huge group of DNA viruses that are responsible for various infections and diseases (27). The members of the family herpesviridae are called herpesviruses. Herpes simplex viruses belong to the herpesviridae family, usually known as herpes - are arranged into two kinds: herpes type 1 (HSV-1) and herpes type 2 (HSV-2). According to the World Health Organization (WHO) report, around $67 \%$ of the world population under age 50 is infected by HSV-1 and $13 \%$ of the world population between ages 15-49 is affected by HSV-2 (28). In the past, various ayurvedic herbs/ plants have been used as herpes virus deterrents. 287 entries (natural ayurvedic products) from the literature have been compiled and included in the AyurVirDB database.

The second most abundant entries are for partially double-stranded DNA Virus Hepatitis B (HBV). Hepatitis B can prompt different illnesses and wellbeing conditions. HBV not only causes hepatitis but sometimes also can activate cirrhosis and hepatocellular carcinoma (29). It has additionally been proposed that it might expand the danger of pancreatic malignancy (30).

In Ayurveda, the cure from HBV is possible with the help of herbs. We gathered this information from different researches and incorporated such 38 entries in the AyurVirDB database.

\section{Ayurvedic Plants against RNA Viruses}

The genetic material is ribonucleic acid (RNA) in the RNA virus. This can be of dualdissimilar typessingle-stranded RNA (ssRNA) and double-stranded RNA (dsRNA). Some of the examples of RNA viruses include Ebola, Dengue virus, Hepatitis C, Influenza, etc. Recently emerged SARS-cov2 virus also belongs to the RNA virus category. The retroviruses are the viruses with RNA as their innate material and they additionally incorporate DNA intermediates in their replication cycle. HIV belongs to the retrovirus category. But in our database, since retroviruses are very few in comparison to DNA and RNA viruses, we are considering HIV under the broad RNA virus category. The RNA virus distribution in the AyurVirDB database is shown in Figure 8. Maximum entries have been found for the HIV in the RNA virus category in the database AyurVirDB.

\section{Figure 8. RNA Virus distribution in AyurVirDB database}

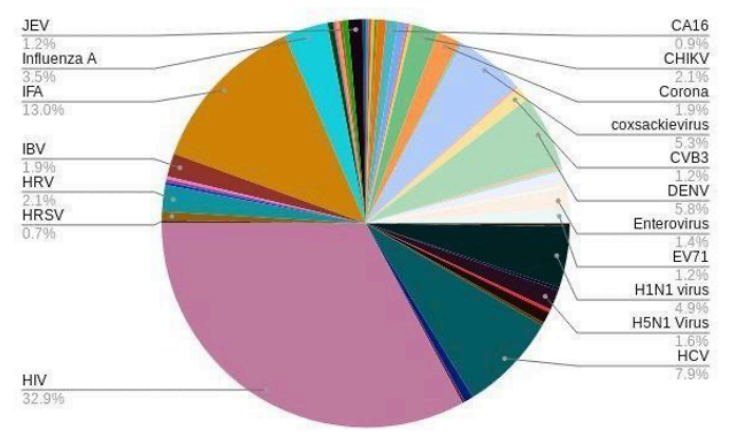

Genus Lentivirus includes the Human immunodeficiency virus (HIV), which is the part of family Retroviridae. HIV Virus attacks the immune system and weakens the protection against numerous diseases. In its later stages of the life cycle, HIV can cause acquired immunodeficiency syndrome (AIDS). According to a WHO report, in the year 2019, 690000 people died due to HIV infections, and 1.7 million individuals were recently infected (31). There are two kinds of HIV viruses namely HIV-1 and HIV-2. HIV-1 is the infection that was first found and named as both lymphadenopathy-related infection (LAV) and human T-lymphotropic infection 3 (HTLV-III). HIV-1 is more adverse and more infectious than HIV-2 (32). The awful HIV can be controlled to quite an extent with the help 
of Ayurveda. 141 such entries were collected from various sources, where herbs are used to treat HIV infection and deposited in the AyurVirDB database.

Influenza viruses are responsible for influenza or common flu. The symptoms of flu can be from mild to severe. There are 4 kinds of seasonal viruses, Influenza $\mathrm{A}, \mathrm{B}, \mathrm{C}$, and $\mathrm{D}$. $\mathrm{H} 1 \mathrm{~N} 1$ and $\mathrm{H} 3 \mathrm{~N} 2$ are subtypes of influenza A (IFA). IFA is well known for causing pandemics. 15 entries for IFA and 21 entries for the H1N1 virus were deposited in the AyurVirDB database along with the herbs/plants.

Dengue viruses are the mosquito-borne members of the Flaviviridae family and are the reason for causing Dengue fever. It is the dominant vigorous disease that has been the major concern of not only national but also international public health. High fever, severe headache, and rashes along with vomiting, nausea, severe muscular and joint pain, and eye pain are some of the indications of the occurrence of Dengue fever(33). 25 entries from various literature surveys have been gathered where herbs/plants are used to treat Dengue virus infection.

\section{Web Interface}

The web server is kept up in MySQL at the back end, while the front end is executed with PHP language. The search and browse options to fetch the desired data from the AyurVirDB database have been included.

\section{Database Search}

Users can select a virus in the search menu option. The information related to the selected virus will be displayed. The example input and output on choosing HSV is shown in Figure 9(a) and Figure 9(b). The output displays the ayurvedic herbs that can be used to treat the virus. The output will also contain fields such as natural product name, herb family name, virus name, virus genus, virus family, virus type, virus primary host, disease symptoms, herb origin, virus origin country, etc.

Figure 9. (a) Select option to choose a virus name (b) Output of virus search

(a)

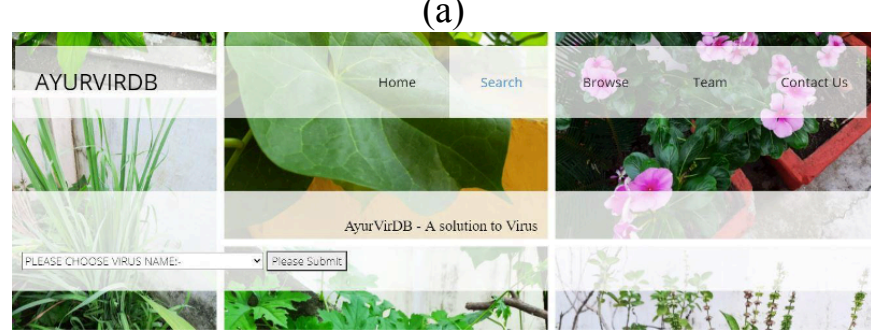

(b)

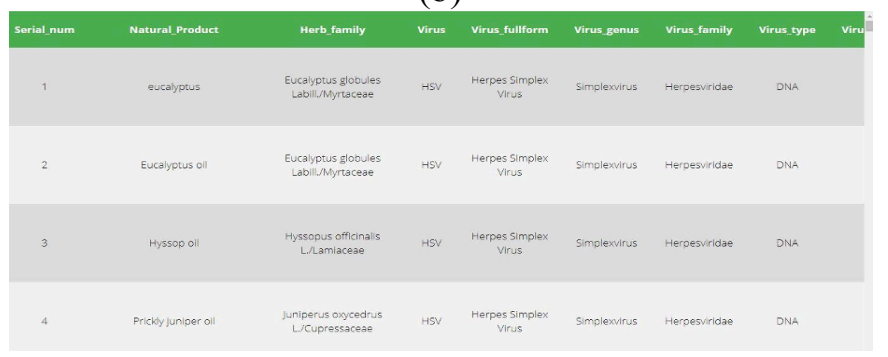

\section{urvedic database for virus cure}

\section{Database Browse}

The database browse option allows the user to browse natural products and virus names (Figure 10(a)). When a user browses for a natural product, the list of all-natural products along with their occurrences in the database will be displayed (Figure 10(b)). Similarly, if a user browses for a virus name, the list of all viruses along with their occurrences in the database will be displayed. Further, the details of any particular herb will be displayed by clicking on the option provided (Figure $10(\mathrm{c}))$. It fetches all the data where that herb is effective, against which viruses along with herb family name, virus genus, virus family, virus type, virus primary host, disease symptoms, herb origin, virus origin country, etc. Likewise, if a user continues to browse virus names, he can get the details of that particular virus by using the click option. And the output will be a list of all herbs which are useful in the treatment of that virus.

Figure 10. (a) Browse option to choose a natural product and virus name (b) Natural product browse (c) Output of natural product selected

(a)

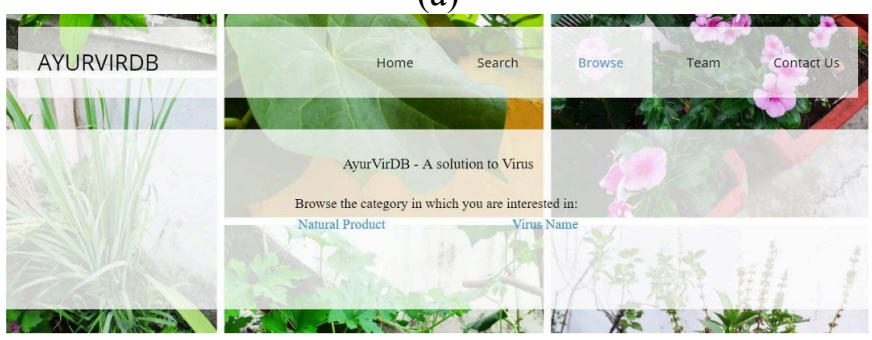

(b)

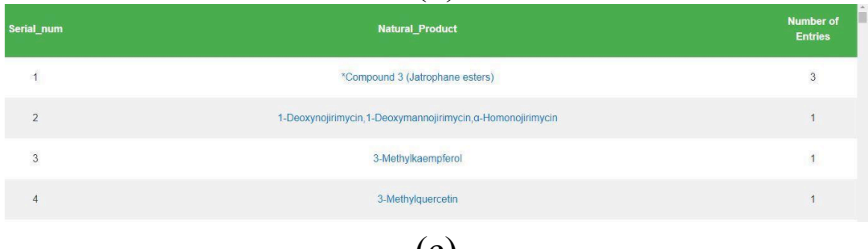

(c)

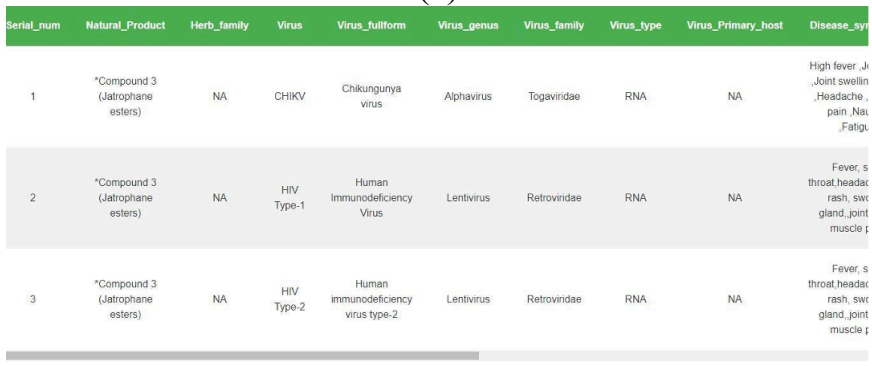

sonnosad fil

\section{Discussion}

As per reports provided by World Health Organization (WHO), $80 \%$ of the total population in various developing nations relies upon customary plants for wellbeing prerequisites. WHO cites 'infectious diseases are the sixth leading cause of premature deaths all over the world' (34). Due to the emergence and reemergence of various infectious diseases, the human population consistentlyfaces predictable risk, out of these infectious diseases, viral infections particularly challenge the perseverance of mankind (35). 
Conventional Indian medication (Ayurveda) is becoming prominent with numerous ongoing conditions as it has been progressively observed that sick people have been treated and prevented against various diseases throughout the centuries by remedies that did not originate from the formal doctrines and procedures of the medical profession. The different types of plants mentioned in Table 1 utilized method used for curing various viral diseases are probably as old as mankind in comparison to formal medicine and medical degrees which are much more recent (36). Past studies indicate that natural products are significant for the treatment of viral infections as well $(37,38)$.

In past, various Ayurvedic medicinal plants databases have been made such as IMPPAT (39), Pytochemica (40), CVDHD (41), KNApSAcK (42), NutriChem (43), TCMID (44), PhytoMolecularTasteDB (45), which help user to virtually scan ayurvedic drugs and their association with certain diseases. AyurVirDB is a comprehensive collection of ayurvedic herbs and viruses. All the information is gathered from the available literature. AyurVirDB consists of details of 104 viruses and 704 natural components.

\section{Conclusion}

A considerable number of plants have been investigated for their antiviral property as the herbal preparations improve the immunity of our body due to their comprehensive approach in turn that helps human body to fight against different viruses that causes infection. Today, herbal antiviral compounds due to their accessibility and less required pharmaceutical synthesis are emerging out to be an effective alternative for growing resistance to antiviral drug therapy. There are various existing herbal treatments for viral diseases which promise to prove their efficiency and safe utilization in advanced clinical trials. Although ample work can be done to regulate optimal treatments, formulae, and doses for these herbal preparations. However, the utilization of herbal plants derived preparations is observed worldwide either individually or in combination yet no data exist related to the interactions of these medicinal plants in the living system. Hence, there is a great need to club these traditional medicine practices with the scientific research aspect which can facilitate modern drug discovery from phytochemicals. So, the databases like

AyurVirDB can be of tremendous utility for researchers and educators since the known harmful, long-lasting effects of synthetic molecules have always made humanity crave newer, safer, and versatile drug resources. Moreover, Ayurveda with its roots imbibed in our culture and conscience has always been an inspiration for discovering newer elixirs of life. The same has been compiled in the database AyurVirDB where the greenway or herbal way as a combat strategy against deadly viruses can be designed and properly executed since the major findings of major research groups are accumulated at the central repository. Moreover, to the best of our knowledge, this is the first database of its kind. The user-friendly Graphical User
Interface (GUI) and comprehensive collection of plants with known activity against viral pathogens can not only supplement research but also eliminate the need to surf multiple resources. Therefore, by adopting these approaches, one can transform the idea of incorporation and implementation of a specific herbal formulation in their routine therapy in real terms.

\section{Website link}

http://ayurvir.com

\section{Conflict of Interests}

There is no conflict of interest among authors.

\section{References}

1. Narayanaswamy V. Origin and development of ayurveda: (a brief history). Ancient science of life. 1981;1(1):1-7.

2. Lakhotia SC. Translating Ayurveda's Dosha-Prakriti into objective parameters. Journal of Ayurveda and integrative medicine. 2014;5(3):176.

3. Paykel ES, DiMascio A, Klerman GL, Prusoff BA, Weissman MM. Maintenance therapy of depression. Pharmakopsychiatrie, Neuro-Psychopharmakologie. 1976;9(3):127-39.

4. Yuan H, Ma Q, Ye L, Piao G. The Traditional Medicine and Modern Medicine from Natural Products. Molecules. 2016;21(5).

5. 2019. WgrotacmGWHO.

6. Goyal M. Threats and challenges of emerging viral diseases and scope of Ayurveda in its prevention. Ayu. 2019;40(2):67-8.

7. De Clercq E, Li G. Approved Antiviral Drugs over the Past 50 Years. Clinical microbiology reviews. 2016;29(3):695-747.

8. Cohen FS. How Viruses Invade Cells. Biophysical journal. 2016;110(5):1028-32.

9. Nanbo A, Imai M, Watanabe S, Noda T, Takahashi K, Neumann G, et al. Ebolavirus is internalized into host cells via macropinocytosis in a viral glycoproteindependent manner. PLoS pathogens. 2010;6(9):e1001121.

10. Lee JK, Shin OS. Advances in Zika Virus(-)Host Cell Interaction: Current Knowledge and Future Perspectives. International journal of molecular sciences. 2019;20(5).

11. Sager G, Gabaglio S, Sztul E, Belov GA. Role of Host Cell Secretory Machinery in Zika Virus Life Cycle. Viruses. 2018;10(10).

12. Samrat SK, Tharappel AM, Li Z, Li H. Prospect of SARS-CoV-2 spike protein: Potential role in vaccine and therapeutic development. Virus research. 2020;288:198141.

13. Rastogi S, Pandey DN, Singh RH. COVID-19 pandemic: A pragmatic plan for ayurveda intervention. Journal of Ayurveda and integrative medicine. 2020.

14. Golechha M. Time to realise the true potential of Ayurveda against COVID-19. Brain, behavior, and immunity. 2020;87:130-1. 
15. Chauhan A, Semwal DK, Mishra SP, Semwal RB Ayurvedic research and methodology: Present status and future strategies. Ayu. 2015;36(4):364-9.

16. Cassa Macedo A, Oliveira Vilela de Faria A, Ghezzi P. Boosting the Immune System, From Science to Myth: Analysis the Infosphere With Google. Frontiers in medicine. 2019;6:165.

17. Pandey MM, Rastogi S, Rawat AK. Indian traditional ayurvedic system of medicine and nutritional supplementation. Evidence-based complementary and alternative medicine :eCAM. 2013;2013:376327.

18. Kumar D, Arya V, Kaur R, Bhat ZA, Gupta VK, Kumar V. A review of immunomodulators in the Indian traditional health care system. Journal of microbiology, immunology, and infection $=$ Wei mianyugan ran za zhi. 2012;45(3):165-84.

19. Chiang LC, Chiang W, Chang MY, Lin CC. In vitro cytotoxic, antiviral and immunomodulatory effects of Plantago major and Plantago asiatica. The American journal of Chinese medicine. 2003;31(2):225-34.

20. Reis SR, Valente LM, Sampaio AL, Siani AC, Gandini $\mathrm{M}$, Azeredo EL, et al. Immunomodulating and antiviral activities of Uncaria tomentosa on human monocytes infected with Dengue Virus-2. International immunopharmacology. 2008;8(3):468-76.

21. Kalikar MV, Thawani VR, Varadpande UK, Sontakke SD, Singh RP, Khiyani RK. Immunomodulatory effect of Tinospora cordifolia extract in human immunodeficiency virus positive patients. Indian journal of pharmacology. 2008;40(3):107-10.

22. Ilyas U, Katare DP, Aeri V, Naseef PP. A Review on Hepatoprotective and Immunomodulatory Herbal Plants. Pharmacognosy reviews. 2016;10(19):66-70.

23. Chattopadhyay D, Sarkar MC, Chatterjee T, Sharma Dey R, Bag P, Chakraborti S, et al. Recent advancements for the evaluation of anti-viral activities of natural products. New biotechnology. 2009;25(5):347-68.

24. Divya M, Vijayakumar S, Chen J, Vaseeharan B, Duran-Lara EF. South Indian medicinal plants can combat deadly viruses along with COVID-19? - A review. Microbial pathogenesis. 2020;148:104277.

25. Mukhtar M, Arshad M, Ahmad M, Pomerantz RJ, Wigdahl B, Parveen Z. Antiviral potentials of medicinal plants. Virus research. 2008;131(2):111-20.

26. Ruffa MJ, Wagner ML, Suriano M, Vicente C, Nadinic J, Pampuro $S$, et al. Inhibitory effect of medicinal herbs against RNA and DNA viruses. Antiviral chemistry \& chemotherapy. 2004;15(3):153-9.

27. Beswick TS. The origin and the use of the word herpes. Medical history. 1962;6:214-32.

28. https://www.who.int/en/news-room/fact-sheets/detail/ herpes-simplex-virus. Last accessed January 2021.

29. Chun Shen Lim \& Chris M. Brown (2016) Hepatitis B virus nuclear export elements: RNA stem-loop $\alpha$ and $\beta$ kpotHp-tre.
30. Hassan MM, Li D, El-Deeb AS, Wolff RA, Bondy ML, Davila M, et al. Association between hepatitis B virus and pancreatic cancer. Journal of clinical oncology : official journal of the American Society of Clinical Oncology. 2008;26(28):4557-62.

31. https://www.who.int/news-room/fact-sheets/detail/hivaids. Last accessed January 2021

32. Gilbert PB, McKeague IW, Eisen G, Mullins C, Gueye NA, Mboup S, et al. Comparison of HIV-1 and HIV-2 infectivity from a prospective cohort study in Senegal. Statistics in medicine. 2003;22(4):573-93.

33. Back AT, Lundkvist A. Dengue viruses - an overview. Infection ecology \& epidemiology. 2013;3.

34. http://www.who.int/mediacentre/factsheets/fs310/en/. Last accessed January 2021.

35. Ganjhu RK, Mudgal PP, Maity H, Dowarha D, Devadiga S, Nag S, et al. Herbal plants and plant preparations as remedial approach for viral diseases. Virusdisease. 2015;26(4):225-36.

36. Ashraf MA, Khatun A, Sharmin T, Mobin F, Tanu AR, Morshed T, et al. MPDB 1.0: a medicinal plant database of Bangladesh. Bioinformation. 2014;10(6):384-6.

37. Medicinal plants and primary health care: part 2 . Essential drugs monitor. 1991(11):15-7.

38. Mahady GB. Global harmonization of herbal health claims. The Journal of nutrition. 2001;131(3s):1120S-3S.

39. Mohanraj K, Karthikeyan BS, Vivek-Ananth RP, Chand RPB, Aparna SR, Mangalapandi $\mathrm{P}$, et al. IMPPAT: A curated database of Indian Medicinal Plants, Phytochemistry And Therapeutics. Scientific reports. 2018;8(1):4329.

40. Pathania S, Ramakrishnan SM, Bagler G. Phytochemica: a platform to explore phytochemicals of medicinal plants. Database : the journal of biological databases and curation. 2015;2015.

41. Gu J, Gui Y, Chen L, Yuan G, Xu X. CVDHD: a cardiovascular disease herbal database for drug discovery and network pharmacology. Journal of cheminformatics. 2013;5(1):51.

42. Afendi FM, Okada T, Yamazaki M, Hirai-Morita A, Nakamura Y, Nakamura K, et al. KNApSAcK family databases: integrated metabolite-plant species databases for multifaceted plant research. Plant \& cell physiology. 2012;53(2):e1.

43. Jensen K, Panagiotou G, Kouskoumvekaki I. NutriChem: a systems chemical biology resource to explore the medicinal value of plant-based foods. Nucleic acids research. 2015;43(Database issue):D940-5.

44. Xue R, Fang Z, Zhang M, Yi Z, Wen C, Shi T. TCMID: Traditional Chinese Medicine integrative database for herb molecular mechanism analysis. Nucleic acids research. 2013;41(Database issue):D1089-95.

45. Dorin Dragos MG. PhytoMolecularTasteDB: An integrative database on the "molecular taste" of Indian medicinal plants. Data in Brief. 2018;19. 